\title{
Association of cerebrospinal fluid protein biomarkers with outcomes in patients with traumatic and non-traumatic acute brain injury: systematic review of the literature
}

\author{
Carlos A. Santacruz ${ }^{1,2}$, Jean-Louis Vincent ${ }^{1 *}$ (D) Andres Bader ${ }^{1}$, Luis A. Rincón-Gutiérrez ${ }^{1}$, \\ Claudia Dominguez-Curell ${ }^{1}$, David Communi ${ }^{3}$ and Fabio S. Taccone ${ }^{1}$
}

\begin{abstract}
Background: Acute brain injuries are associated with high mortality rates and poor long-term functional outcomes. Measurement of cerebrospinal fluid (CSF) biomarkers in patients with acute brain injuries may help elucidate some of the pathophysiological pathways involved in the prognosis of these patients.

Methods: We performed a systematic search and descriptive review using the MEDLINE database and the PubMed interface from inception up to June 29, 2021, to retrieve observational studies in which the relationship between CSF concentrations of protein biomarkers and neurological outcomes was reported in patients with acute brain injury [traumatic brain injury, subarachnoid hemorrhage, acute ischemic stroke, status epilepticus or post-cardiac arrest]. We classified the studies according to whether or not biomarker concentrations were associated with neurological outcomes. The methodological quality of the studies was evaluated using the Newcastle-Ottawa quality assessment scale.

Results: Of the 39 studies that met our criteria, 30 reported that the biomarker concentration was associated with neurological outcome and 9 reported no association. In TBI, increased extracellular concentrations of biomarkers related to neuronal cytoskeletal disruption, apoptosis and inflammation were associated with the severity of acute brain injury, early mortality and worse long-term functional outcome. Reduced concentrations of protein biomarkers related to impaired redox function were associated with increased risk of neurological deficit. In non-traumatic acute brain injury, concentrations of CSF protein biomarkers related to dysregulated inflammation and apoptosis were associated with a greater risk of vasospasm and a larger volume of brain ischemia. There was a high risk of bias across the studies.
\end{abstract}

Conclusion: In patients with acute brain injury, altered CSF concentrations of protein biomarkers related to cytoskeletal damage, inflammation, apoptosis and oxidative stress may be predictive of worse neurological outcomes.

Keywords: Traumatic brain injury, Cerebrospinal fluid, Subarachnoid hemorrhage, Neurological outcomes

*Correspondence: jlvincent@intensive.org

1 Department of Intensive Care, Erasme University Hospital, Université Libre de Bruxelles, Route De Lennik 808, 1070 Brussels, Belgium

Full list of author information is available at the end of the article

\section{Introduction}

Acute brain injuries are a group of neurological insults to the brain parenchyma and are associated with poor longterm functional outcomes and high mortality rates [1]. Primary brain injuries represent the initial insult to the original author(s) and the source, provide a link to the Creative Commons licence, and indicate if changes were made. The images or other third party material in this article are included in the article's Creative Commons licence, unless indicated otherwise in a credit line to the material. If material is not included in the article's Creative Commons licence and your intended use is not permitted by statutory regulation or exceeds the permitted use, you will need to obtain permission directly from the copyright holder. To view a copy of this licence, visit http://creativecommons.org/licenses/by/4.0/. The Creative Commons Public Domain Dedication waiver (http://creativeco mmons.org/publicdomain/zero/1.0/) applies to the data made available in this article, unless otherwise stated in a credit line to the data. 
brain and are usually considered non-reversible. Secondary brain injuries arise from insults to the brain parenchyma that occur after the initial injury (e.g., as a result of hypoxemia and/or hypotension) and increase the overall area of damaged brain tissue [2,3]. After an acute brain injury, intrathecal expression of proteins related to brain inflammation, apoptosis and oxidative stress induces production and migration of chemotactic factors, which ultimately lead to blood-brain barrier (BBB) dysfunction, brain edema formation and intracranial hypertension [4]. This cellular response may render the brain more susceptible to secondary injuries in cases of decreased cerebral perfusion pressure and may increase the volume of nonviable tissue.

In humans, the cerebrospinal fluid (CSF) acts as a highly specific repository of cellular by-products, neurotransmitters and protein fragments as it is in close contact with the brain parenchyma and other products of neural origin [5]. Concentrations of protein biomarkers in the intrathecal space may therefore reflect the presence or severity of primary and/or secondary brain injuries. For example, in patients with traumatic brain injury (TBI), increased CSF concentrations of protein biomarkers from damaged neurons may serve as indicators of ongoing cellular damage [6], and, in patients with subarachnoid hemorrhage $(\mathrm{SAH})$, higher concentrations of CSF protein biomarkers may be associated with increased risk of vasospasm and delayed cerebral ischemia [7]. CSF protein biomarkers may reflect the pathophysiological pathways involved in acute brain injuries that could be susceptible to interventions, and thus help in the development of therapies or to guide earlier intervention to improve long-term functional outcomes.

We therefore performed a systematic review to identify observational studies that have evaluated the relationship between CSF protein biomarkers in patients with acute brain injuries and neurological outcomes.

\section{Materials and methods Data sources}

Following protocol submission to the Prospero International Prospective Register of Systematic Reviews (ID 114294), we conducted a systematic search of the literature using the MEDLINE database and the PubMed interface from inception until June 29, 2021, to identify all observational studies that evaluated CSF protein biomarkers (proteins were defined as those with at least 50 amino acids or a molecular weight greater than $4000 \mathrm{Da}$ ) in patients with severe acute brain injury (as a result of TBI, SAH, acute ischemic stroke, status epilepticus or post-cardiac arrest syndrome) and that reported any neurological outcome. We used the MeSH terms: ((((("Brain Injuries, Traumatic"[MeSH]) OR "Subarachnoid
Hemorrhage" [MeSH]) OR "Stroke" [MeSH]) OR "Status Epilepticus"[MeSH]) OR "Post-Cardiac Arrest Syndrome" $[\mathrm{MeSH}]$ ) AND "Biomarkers" $[\mathrm{MeSH}]$. The search limits were clinical studies, human, adults $19+$ (over 18 years of age) and articles written in English. We also searched the references of included articles for studies that had been missed in the initial search. We followed the Preferred Reporting Items for Systematic Reviews and Meta-Analysis (PRISMA) statement [8].

\section{Study selection and data abstraction}

Three of the authors (AB, LARG and CDC) performed the literature search and selected the studies. We excluded studies on descriptive proteomics; those evaluating metabolites (e.g., lactate, lactate/pyruvate, glucose, glutamate, glycerol, etc.), hormones or cytokines/ chemokines; those in patients with chronic degenerative or chronic traumatic injuries (e.g., multiple sclerosis, Alzheimer and Parkinson diseases, sport-related injuries, chronic traumatic encephalopathy); those in patients with autoimmune conditions (e.g., Guillain-Barré); pediatric studies; postmortem populations; studies with only physiological outcomes; and animal studies. Data abstraction regarding type of acute brain injury, source of CSF (ventricular or lumbar), number of included subjects, method used by the author to quantify the specific biomarker and neurological outcomes was performed by the same three reviewers (AB, LARG and CDC) in an independent blinded manner by completing predefined tables. Studies were classified according to whether or not the measured biomarker was associated with neurological outcome (as defined in the original study) and were grouped according to whether the brain injury was traumatic or non-traumatic. The methodological quality of the observational studies was evaluated using the Newcastle-Ottawa quality assessment scale [9]. Discrepancies in the assessment of methodologic quality and final classification of the selected studies were resolved by the involvement of a fourth author (CAS).

\section{Results}

The initial search yielded 557 citations, and 39 studies met the inclusion criteria (Fig. 1). These studies had evaluated 27 CSF protein biomarkers; 26 studies had evaluated the relationship of a protein biomarker in acute brain injuries of traumatic origin $[10,12,15,17-22$, $24-29,32,34,36,39,41-47], 11$ in acute brain injuries of non-traumatic origin $[7,11,13,16,23,30,31,33,35$, $37,38]$ and two in acute brain injuries of mixed (traumatic and non-traumatic) origin $[14,40]$. No study had reported CSF biomarkers after cardiac arrest. Thirty studies $[7,10-38]$ reported an association of the protein 


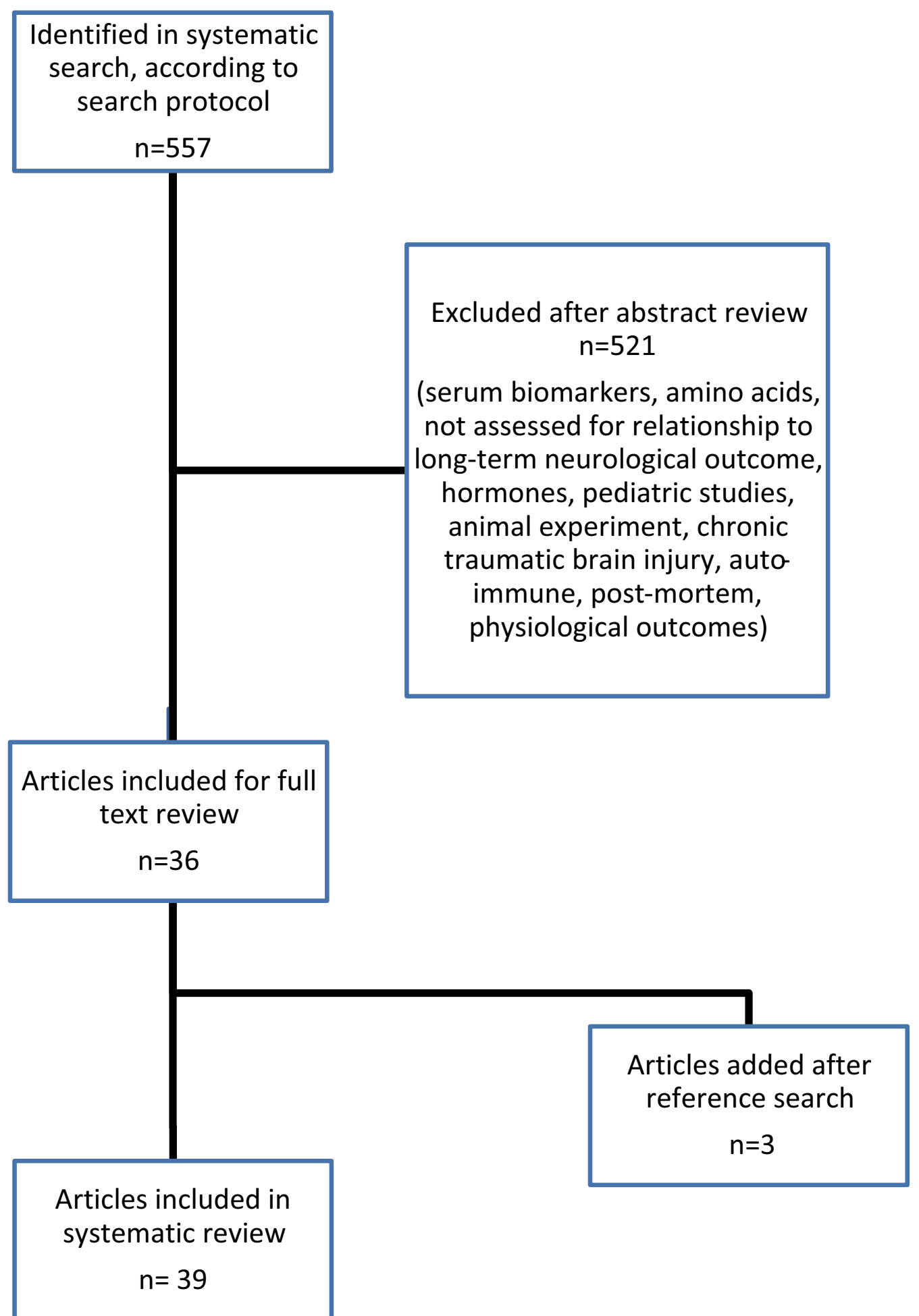

Fig. 1 Flowchart of included studies 


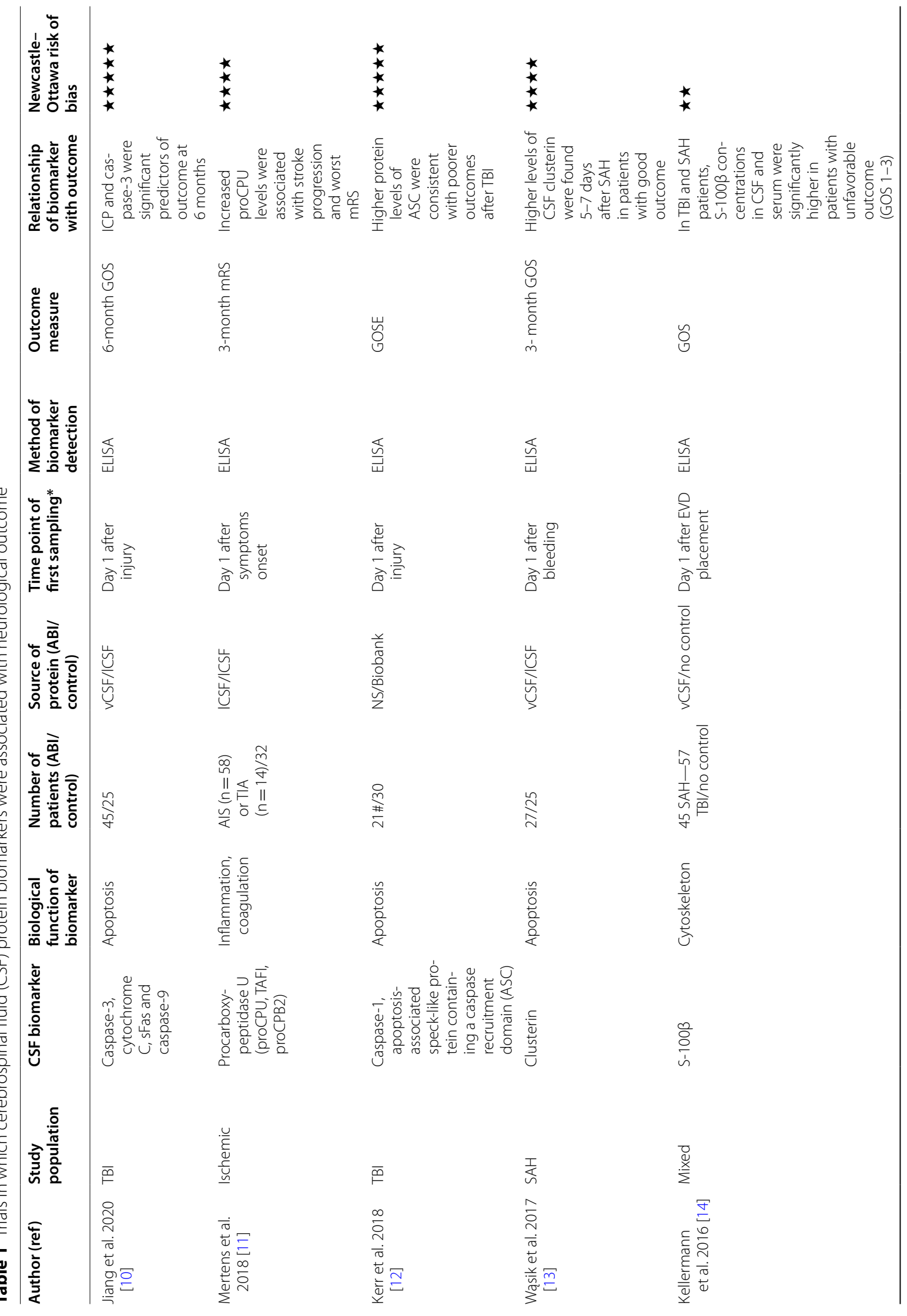




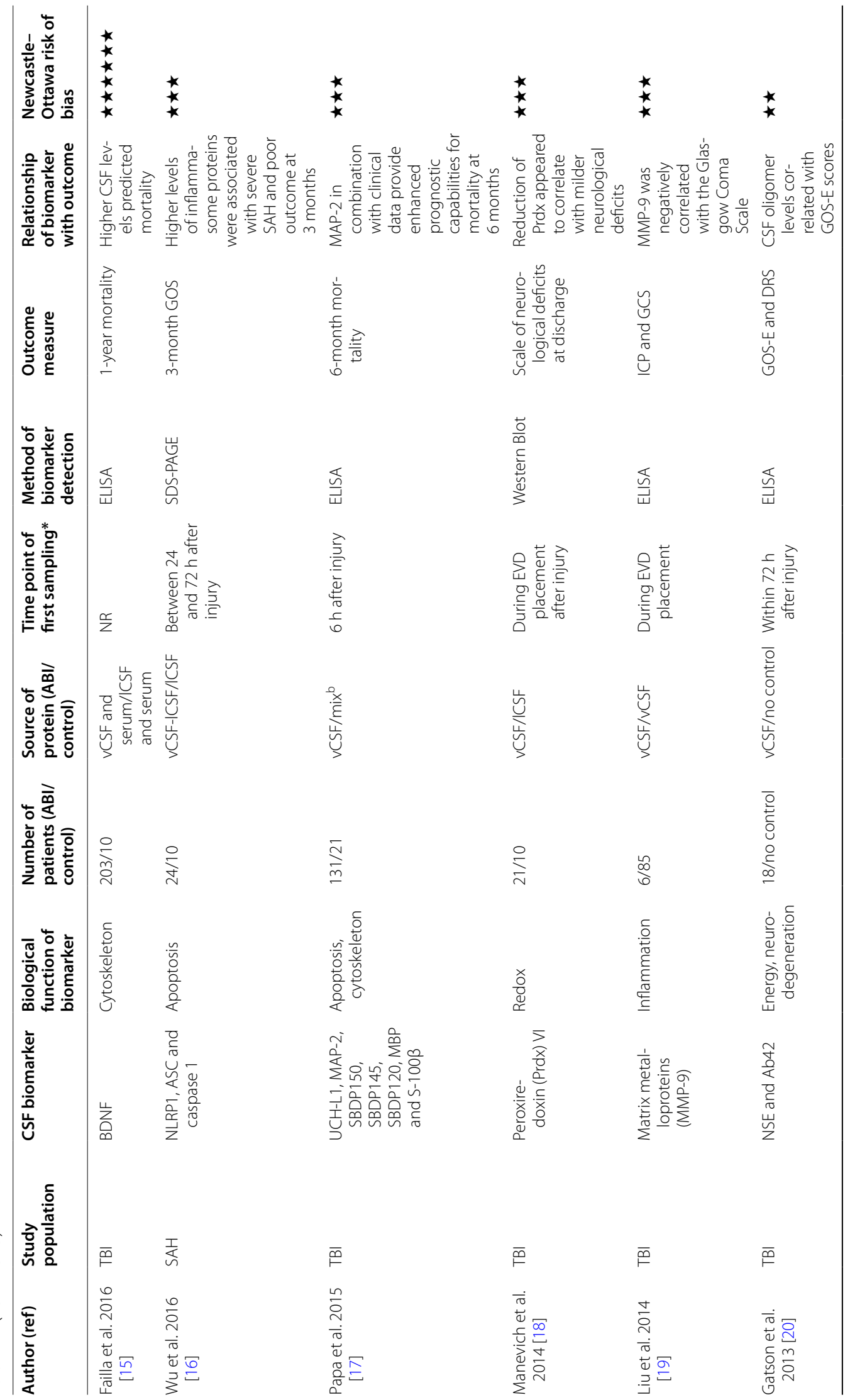




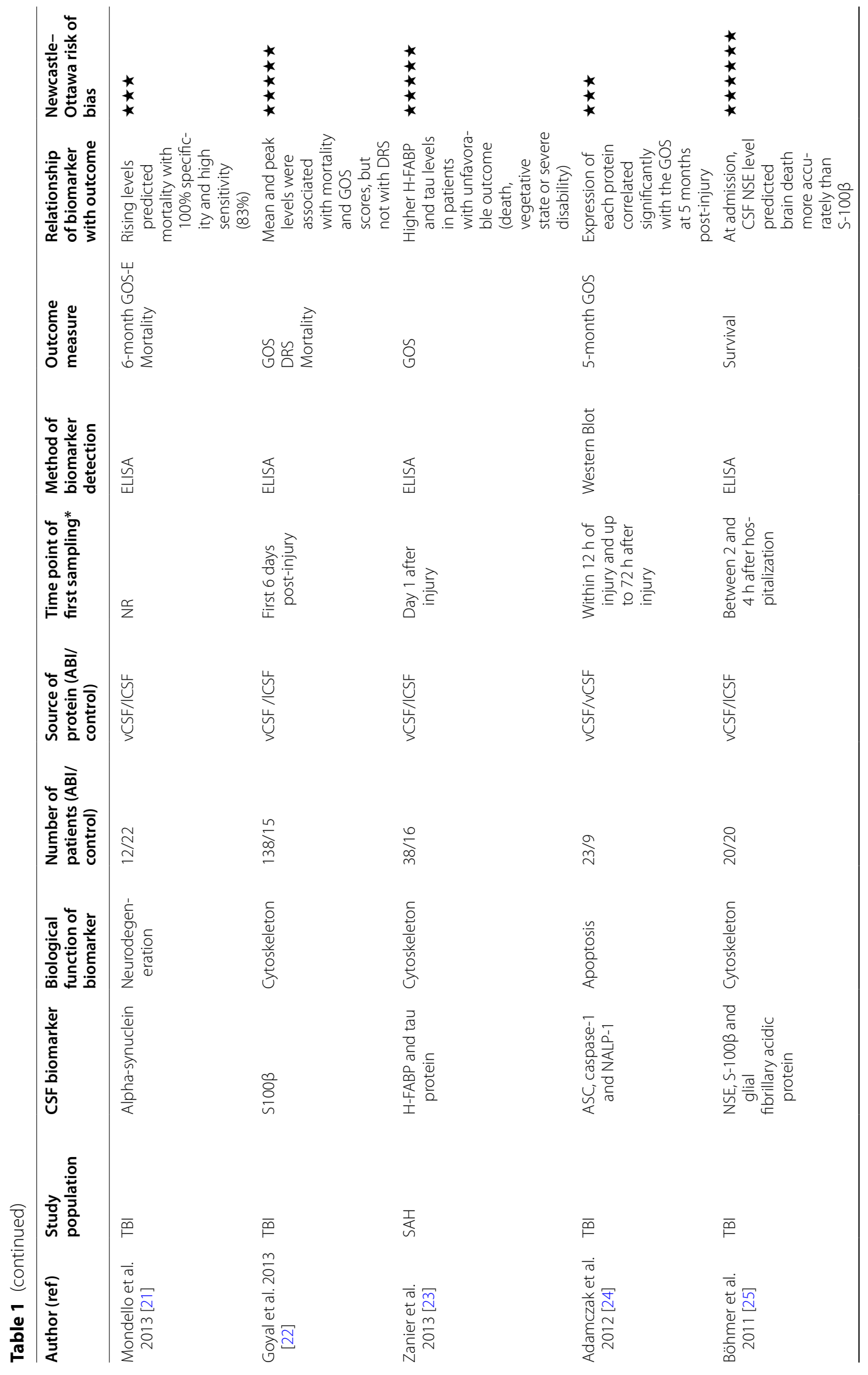




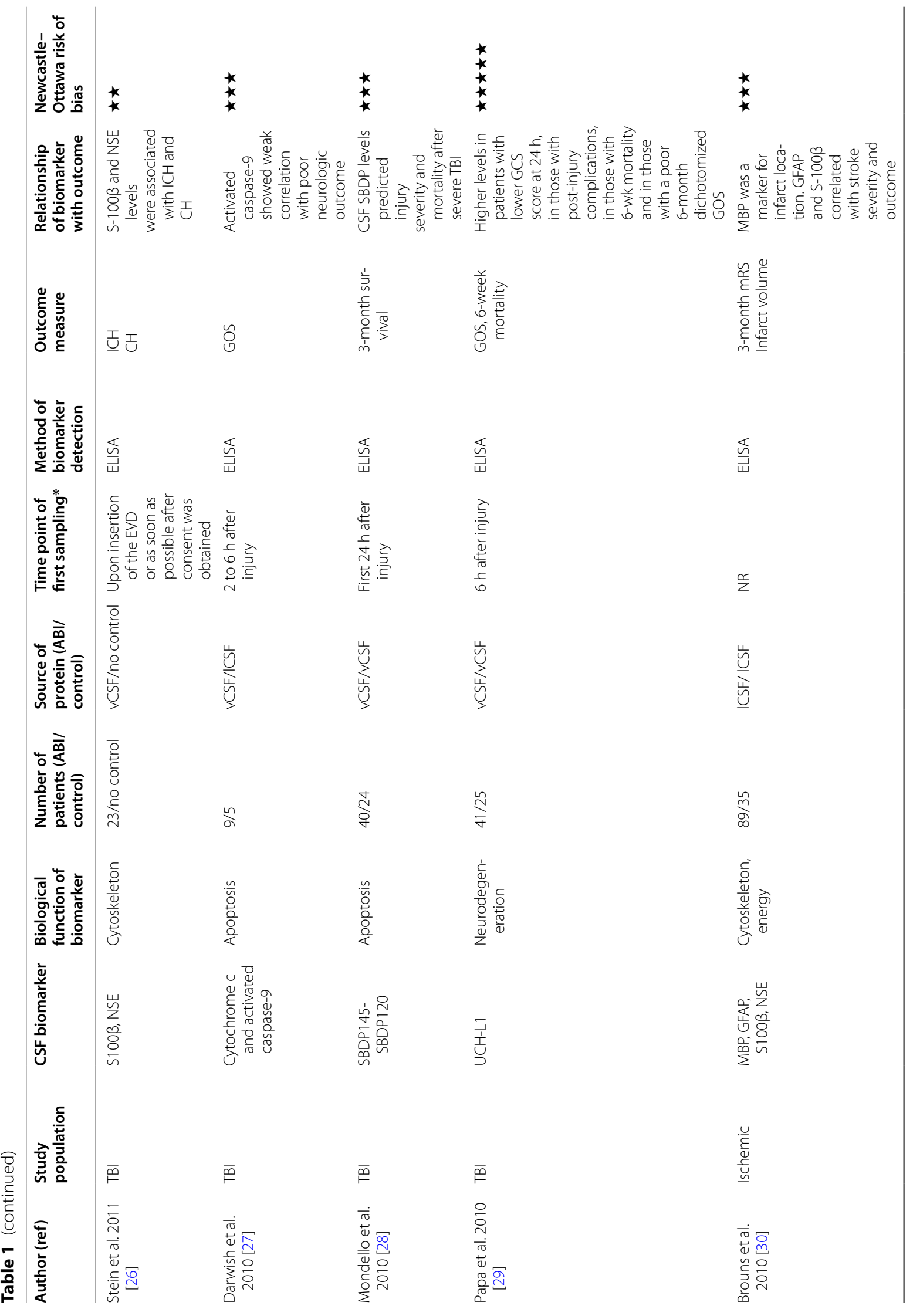




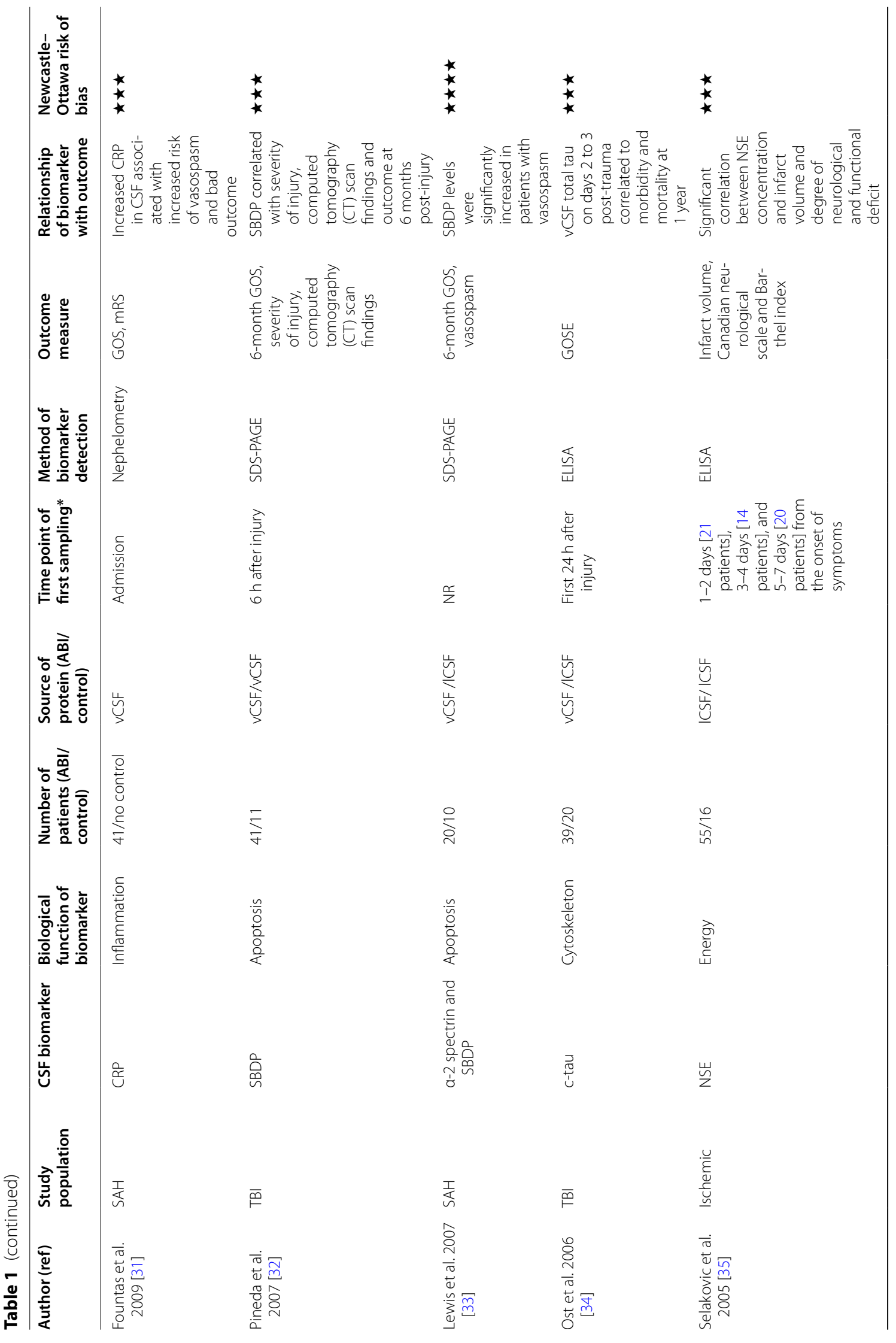




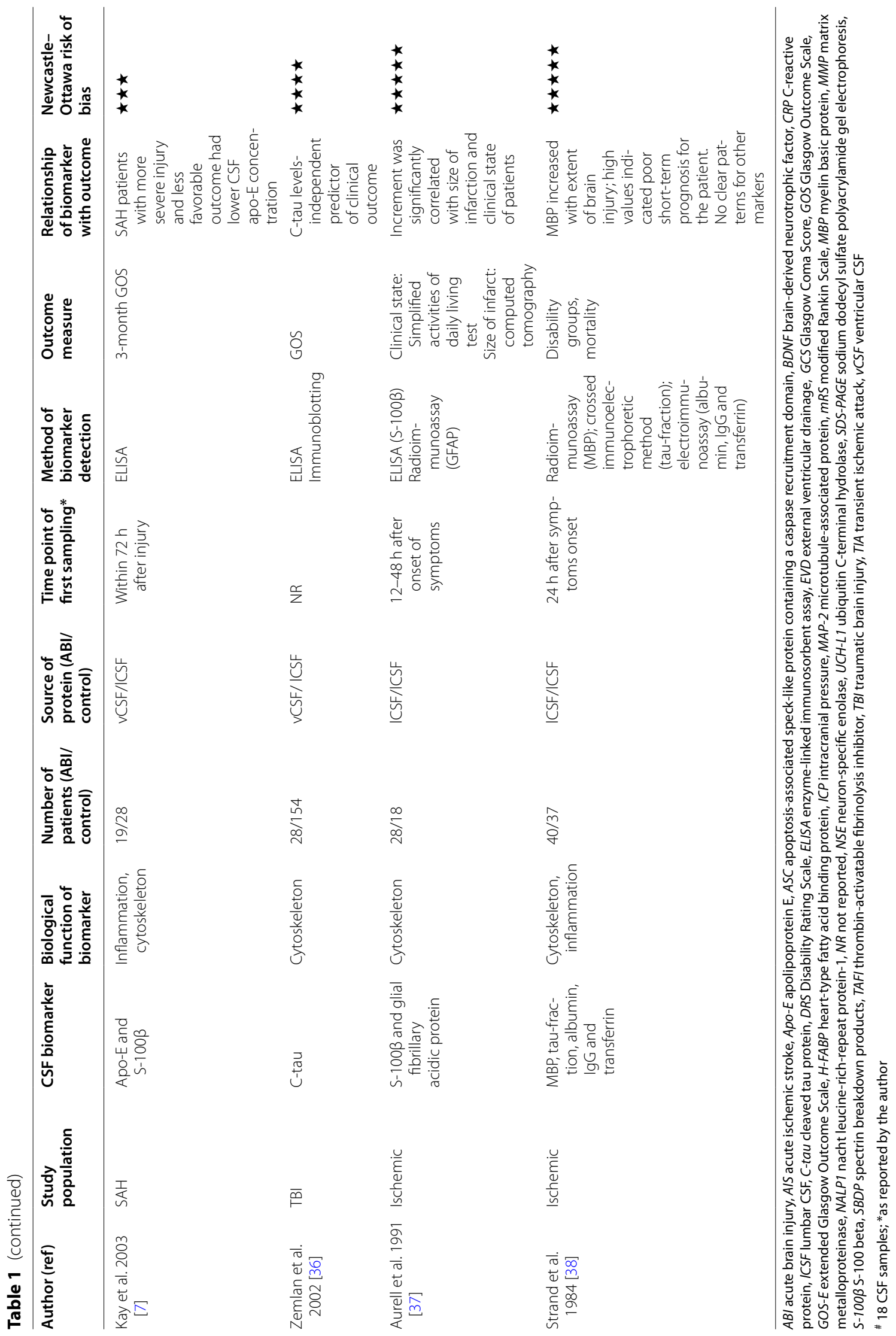




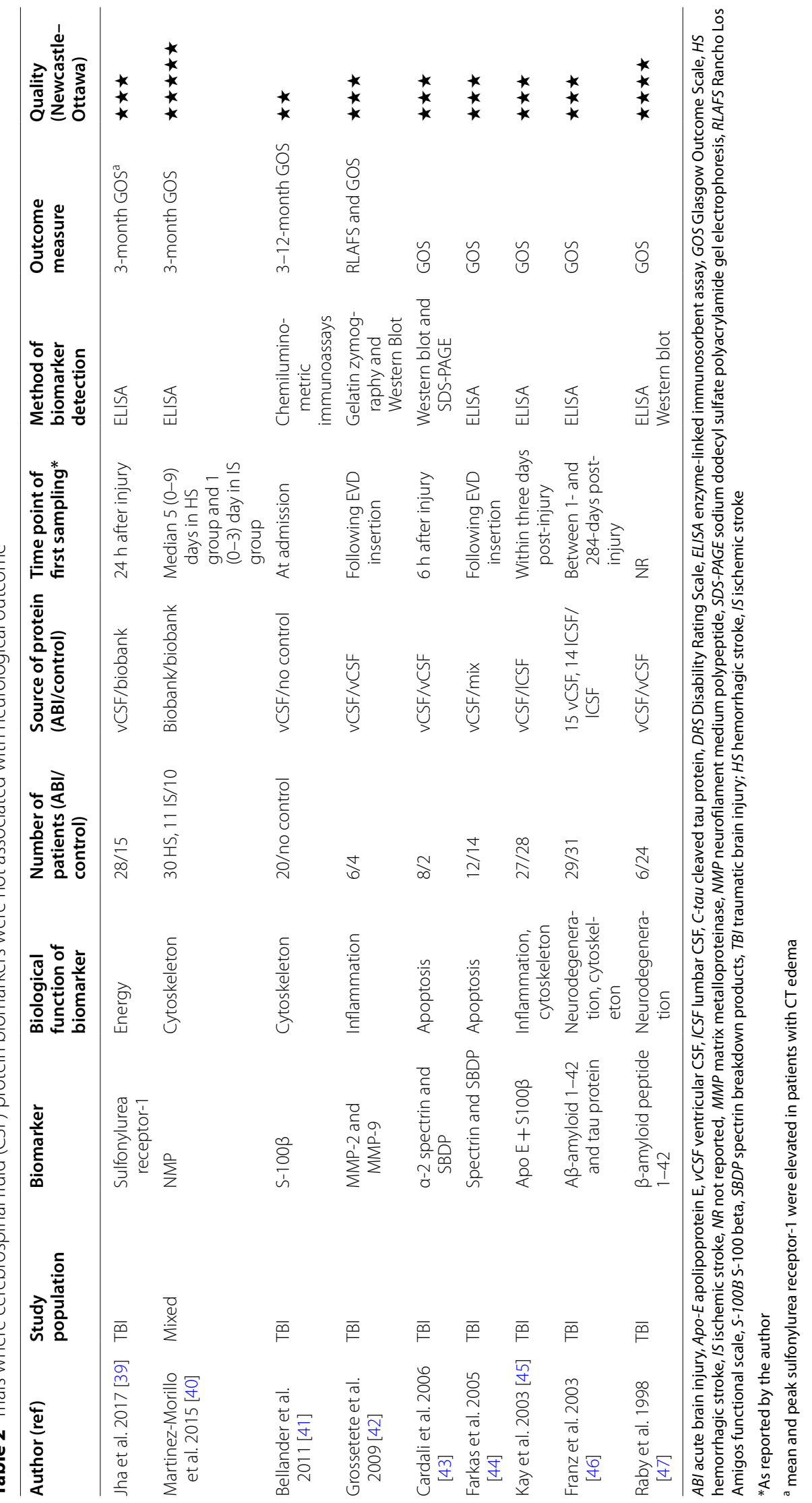


biomarker with neurological outcome (Table 1), and 9 reported no association [39-47] (Table 2).

\section{Observational trials reporting biomarker associations with neurological outcome}

Of the 30 trials that reported a biomarker associated with outcome, 18 included patients with TBI $(n=1345), 6$ included patients with SAH $(\mathrm{n}=258), 5$ included patients with acute ischemic stroke $(n=422)$, and one included a mixed population (TBI and SAH) $(n=102)$. The main biological functions reflected by the biomarkers were related to primary brain injury (neuron cell cytoskeleton) and secondary brain injury, e.g., increased apoptosis, inflammation and energy metabolism, reduced redox response to oxidative stress and increased neurodegeneration. Specifically, concentrations of the CSF biomarkers ubiquitin carboxy-terminal hydrolase L1 (UCH-L1), microtubule-associated protein (MAP)-2, alpha-synuclein and peroxiredoxin VI were associated with a lower Glasgow Coma Scale (GCS) score on admission, worse long-term functional outcome and increased mortality. In patients with SAH, NLRP1, ASC (apoptosis-associated speck-like protein containing a caspase recruitment domain), caspase- 1 and 3, $\alpha-2$ spectrin and SBDP (spectrin breakdown products), apolipoprotein-E, S-100 $\beta$, H-FABP (heart-type fatty acid binding protein) and tau protein were associated with an increased risk of vasospasm, late cerebral ischemia and worse functional outcome at 3-6 months. These findings were consistent when the CSF was collected from a mixed cohort of TBI and SAH patients. In patients with acute ischemic stroke, proteins related to cytoskeleton disruption and energy metabolism were consistently associated with the size of brain infarction and clinical status (see Table 1).

\section{Observational trials reporting no association of the biomarker with neurological outcome}

Of the 9 trials that reported no association of the biomarker with neurological outcome [39-47], 8 included patients with TBI $(\mathrm{n}=254)$ and 1 had a mixed population of patients with hemorrhagic or ischemic stroke $(n=51)$. The main biological functions assessed by the studied biomarkers included inflammation, neuronal cytoskeleton components, apoptosis, energy metabolism and neurodegeneration (Table 2 ).

\section{Methodological analysis}

The risk of bias among the included studies was high according to the Newcastle-Ottawa scale [9] (Tables 1 and 2). In addition, different CSF sources were used for assessment of protein biomarker concentrations (ventricular CSF, lumbar CSF, serum, biobanks) across different studies and most control group patients also had neurological conditions that may have influenced biomarker concentrations (e.g., normal pressure hydrocephalus). The studies of patients with acute ischemic stroke were the only ones in which the source of CSF was always the same in the intervention and the control group (lumbar CSF).

\section{Discussion}

Our results suggest that CSF concentrations of protein biomarkers associated with the pathophysiological pathways involved in acute brain injuries may be predictive of increased morbidity and mortality after traumatic and non-traumatic acute brain injury.

CSF proteomic expression may be altered by many factors including genetic background, the severity of the primary brain injury and secondary insults, such as hypoxemia and hypotension $[48,49]$. In patients with a traumatic origin of the acute brain injury, cytoskeletal damage was associated with an increased risk of cerebral hemorrhage, intracranial hypertension and early mortality rates, suggesting severe primary brain injuries. After the initial phase of acute brain injury, the expression of proteins involved in re-establishing normal homeostasis is altered [50]. If this response is dysregulated, it may overwhelm counter-regulatory measures initiated by the body to reduce tissue injury, increasing the risk of secondary brain injuries [51]. Moreover, impairment of normal biological functions (e.g., redox function capability, dysregulated inflammation, increased apoptosis) after a primary acute brain injury may render the brain more susceptible to secondary injuries. This seems to be the case in patients with SAH in whom CSF concentrations of C-reactive protein [31], $\alpha-2$ spectrin and SBDP [33], apolipoprotein E [7], H-FABP and tau protein [23] were associated with an elevated risk of vasospasm and delayed cerebral ischemia. Interestingly, in a mixed population of patients with traumatic and non-traumatic acute brain injuries, concentrations of the structural protein S-100 $\beta$ were higher in patients with lower Glasgow Outcome Scale (GOS) scores [14], suggesting a common pathophysiological pathway for these two types of injury.

Consequences such as acute brain edema, vasospasm or non-convulsive status epilepticus are of crucial importance in patients with acute brain injury because they may affect long- and short-term outcomes. Jha et al. [39] evaluated the ability of the protein biomarker sulfonylurea receptor-1 (Sur1) to predict the risk of cerebral edema in patients with severe TBI. Patients with evidence of edema on computed tomography (CT) had higher concentrations of Sur1 with statistically significant differences in mean $(p=0.023)$ and peak $(p=0.019)$ concentrations in patients with and without edema. Although there were no differences in functional outcome, as 
assessed using the 3-month GOS score, in patients with higher Sur1 concentrations, prediction of cerebral edema may indicate the need for more aggressive therapeutic measures.

It is difficult to imagine that a single biomarker could explain the complex cascades of events following acute brain injury that may be related to worse long-term outcomes. A single CSF protein biomarker may indicate derangement of a specific biological function but may not be involved in other pathophysiological pathways. Moreover, the time point at which the biomarker is measured may reflect different stages of acute brain injury (e.g., primary vs secondary injury). Thus, earlier sampling of CSF biomarkers after initial injury may provide information about the severity of the initial injury (e.g., increased risk of early mortality, extent of brain tissue involvement, risk of severe intracranial pressure), whereas more delayed measurements could provide information on risk of chronic degenerative encephalopathy or longer-term outcomes. This could be an interesting area for future study.

Our review has several limitations. First, the search strategy was based solely on the MEDLINE database, and more studies may have been identified if other databases (e.g., Embase) had been used. Second, because of insufficient data we could only provide descriptive data. We were unable to determine which protein biomarker was most associated with worse short- or long-term outcomes. Also, there was a high risk of bias among the included studies because of trials without a control group, a control group with CSF-derived from patients with other neurological conditions (e.g., with normal pressure hydrocephalus) or studies comparing lumbar and ventricular CSF without taking into account the craniocaudal gradient [52]. Finally, some studies used frozen biobank samples, which may have lower protein concentrations because of proteolysis induced by freezethaw and contamination. Future studies should report in a more standardized fashion to enable comparison across different studies.

\section{Conclusions}

Changes to the CSF proteome in patients with acute brain injury reflecting the pathophysiological pathways involved may be indicative of the severity of the injury and predictive of worse neurological outcomes. However, there are currently insufficient data available to recommend the routine measurement of any CSF biomarker in these patients.

\section{Abbreviations}

ABI: Acute brain injury; Apo-E: Apolipoprotein E; CSF: Cerebrospinal fluid; C-tau: Cleaved tau protein; DRS: Disability Rating Scale; ELISA: Enzyme-linked immunosorbent assay; GOS: Glasgow Outcome Scale; GOS-E: Extended Glasgow Outcome Scale; H-FABP: Heart-type fatty acid binding protein; MBP. Myelin basic protein; MMP: Matrix metalloproteinase; NMP: Neurofilament medium polypeptide; NSE: Neuron-specific enolase; RLAFS: Rancho Los Amigos functional scale; SAH: Subarachnoid hemorrhage; SBDP: Spectrin breakdown products; SDS-PAGE: Sodium dodecyl sulfate polyacrylamide gel electrophoresis; Sur1: Sulfonylurea receptor-1; TBI: Traumatic brain injury; UCHL1: Ubiquitin C-terminal hydrolase.

\section{Acknowledgements}

Not applicable

\section{Authors' contributions}

CAS, DC and FT designed the study; AB, LARG and CDC performed the literature search and extracted the data; CAS wrote the first draft of the manuscript; $F T$, JLV, DC, AB, LARG and CDC reviewed the article for critical content; and all authors read and approved the final text.

\section{Funding}

Not applicable.

Availability of data and material

Not applicable.

\section{Declarations}

Ethics approval and consent to participate

Not applicable.

\section{Consent for publication}

Not applicable.

\section{Competing interests}

$J$ JV is Editor-in-Chief of Critical Care. He has no other conflicts of interest. The other authors have no conflicts of interest to declare.

\section{Author details}

${ }^{1}$ Department of Intensive Care, Erasme University Hospital, Université Libre de Bruxelles, Route De Lennik 808, 1070 Brussels, Belgium. 'Department of Intensive and Critical Care Medicine, Academic Hospital Fundación Santa Fe de Bogotá, Bogotá, Colombia. Institut de Recherche Interdisciplinaire en Biologie Humaine Et Moléculaire, Université Libre de Bruxelles, Brussels, Belgium.

Received: 4 May 2021 Accepted: 21 July 2021

Published online: 05 August 2021

\section{References}

1. D'Onofrio G, Jauch E, Jagoda A, Allen MH, Anglin D, Barsan WG, Berger RP, Bobrow BJ, Boudreaux ED, Bushnell C, Chan YF, Currier G, Eggly S, Ichord R, Larkin GL, Laskowitz D, Neumar RW, Newman-Toker DE, Quinn J, Shear K, Todd KH, Zatzick D. Roundtable external participants and roundtable steering committee and federal participants. NIH roundtable on opportunities to advance research on neurologic and psychiatric emergencies. Ann Emerg Med. 2010;56:551-64.

2. Kinoshita K. Traumatic brain injury: pathophysiology for neurocritical care. J Intensive Care. 2016:4:29.

3. Hernandez-Ontiveros DG, Tajiri N, Acosta S, Giunta B, Tan J, Borlongan CV. Microglia activation as a biomarker for traumatic brain injury. Front Neurol. 2013:4:30.

4. Hinson HE, Rowell S, Schreiber M. Clinical evidence of inflammation driving secondary brain injury: a systematic review. J Trauma Acute Care Surg. 2015:78:184-91.

5. Romeo MJ, Espina V, Lowenthal M, Espina BH, Petricoin EF 3rd, Liotta LA. CSF proteome: a protein repository for potential biomarker identification. Expert Rev Proteomics. 2005;2:57-70.

6. Zemlan FP, Rosenberg WS, Luebbe PA, Campbell TA, Dean GE, Weiner NE, Cohen JA, Rudick RA, Woo D. Quantification of axonal damage 
in traumatic brain injury: affinity purification and characterization of cerebrospinal fluid tau proteins. J Neurochem. 1999;72:741-50.

7. Kay A, Petzold A, Kerr M, Keir G, Thompson E, Nicoll J. Decreased cerebrospinal fluid apolipoprotein $\mathrm{E}$ after subarachnoid hemorrhage: correlation with injury severity and clinical outcome. Stroke. 2003;34:637-42.

8. Moher D, Liberati A, Tetzlaff J, Altman DG. The PRISMA Group. Preferred reporting items for systematic reviews and meta-analyses: the PRISMA statement. PLoS Med. 2009;6:1000097.

9. Deeks JJ, Dinnes J, D'Amico R, Sowden AJ, Sakarovitch C, Song F, et al. Evaluating non-randomised intervention studies. Health Technol Assess. 2003;7:iii-X, 1-173

10. Jiang W, Jin P, Wei W, Jiang W. Apoptosis in cerebrospinal fluid as outcome predictors in severe traumatic brain injury: an observational study. Medicine (Baltimore). 2020;99:20922.

11. Mertens JC, Leenaerts D, Brouns R, Engelborghs S, leven M, De Deyn PP, Lambeir AM, Hendriks D. Procarboxypeptidase U (proCPU, TAFI, proCPB2) in cerebrospinal fluid during ischemic stroke is associated with stroke progression, outcome and blood-brain barrier dysfunction. J Thromb Haemost. 2018:16:342-8.

12. Kerr N, Lee SW, Perez-Barcena J, Crespi C, Ibañez J, Bullock MR, Dietrich WD, Keane RW, de Rivero Vaccari JP. Inflammasome proteins as biomarkers of traumatic brain injury. PLoS ONE. 2018;13:e0210128.

13. Wąsik N, Sokół B, Hołysz M, Mańko W, Juszkat R, Jagodziński PP, Jankowski R. Clusterin, a new cerebrospinal fluid biomarker in severe subarachnoid hemorrhage: a pilot study. World Neurosurg. 2017;107:424-8.

14. Kellermann I, Kleindienst A, Hore N, Buchfelder M, Brandner S. Early CSF and Serum S-100 $\beta$ concentrations for outcome prediction in traumatic brain injury and subarachnoid hemorrhage. Clin Neurol Neurosurg. 2016;145:79-83.

15. Failla MD, Conley YP, Wagner AK. Brain-derived neurotrophic factor (BDNF) in traumatic brain injury-related mortality: interrelationships between genetics and acute systemic and central nervous system BDNF profiles. Neurorehabil Neural Repair. 2016;30:83-93.

16. Wu Q, Wang XL, Yu Q, Pan H, Zhang XS, Zhang QR, Wang HD, Zhang X. Inflammasome proteins in cerebrospinal fluid of patients with subarachnoid hemorrhage are biomarkers of early brain injury and functional outcome. World Neurosurg. 2016;94:472-9.

17. Papa L, Robertson CS, Wang KK, Brophy GM, Hannay HJ, Heaton S, Schmalfuss I, Gabrielli A, Hayes RL, Robicsek SA. Biomarkers improve clinical outcome predictors of mortality following non-penetrating severe traumatic brain injury. Neurocrit Care. 2015;22:52-64.

18. Manevich Y, Hutchens S, Halushka PV, Tew KD, Townsend DM, Jauch EC, Borg K. Peroxiredoxin VI oxidation in cerebrospinal fluid correlates with traumatic brain injury outcome. Free Radic Biol Med. 2014;72:210-21.

19. Liu CL, Chen CC, Lee HC, Cho DY. Matrix metalloproteinase-9 in the ventricular cerebrospinal fluid correlated with the prognosis of traumatic brain injury. Turk Neurosurg. 2014;24:363-8.

20. Gatson JW, Warren V, Abdelfattah K, Wolf S, Hynan LS, Moore C, DiazArrastia R, Minei JP, Madden C, Wigginton JG. Detection of $\beta$-amyloid oligomers as a predictor of neurological outcome after brain injury. J Neurosurg. 2013;118:1336-42.

21. Mondello S, Buki A, Italiano D, Jeromin A. a-Synuclein in CSF of patients with severe traumatic brain injury. Neurology. 2013;80:1662-8.

22. Goyal A, Failla MD, Niyonkuru C, Amin K, Fablo A, Berger RP, Wagner AK. S-100 $\beta$ as a prognostic biomarker in outcome prediction for patients with severe traumatic brain injury. J Neurotrauma. 2013;30:946-57.

23. Zanier ER, Zoerle T, Fiorini M, Longhi L, Cracco L, Bersano A, Branca $\checkmark$, Benedetti MD, De Simoni MG, Monaco S, Stocchetti N. Heart-fatty acid-binding and tau proteins relate to brain injury severity and longterm outcome in subarachnoid haemorrhage patients. Br J Anaesth. 2013;111:424-32.

24. Adamczak S, Dale G, de Rivero Vaccari JP, Bullock MR, Dietrich WD, Keane RW. Inflammasome proteins in cerebrospinal fluid of brain-injured patients as biomarkers of functional outcome: clinical article. J Neurosurg. 2012:117:1119-25.

25. Böhmer AE, Oses JP, Schmidt AP, Perón CS, Krebs CL, Oppitz PP, D'Avila TT, Souza DO, Portela LV, Stefani MA. Neuron-specific enolase, S-100 $\beta$, and glial fibrillary acidic protein levels as outcome predictors in patients with severe traumatic brain injury. Neurosurgery. 2011;68:1624-30.
26. Stein DM, Kufera JA, Lindell A, Murdock KR, Menaker J, Bochicchio GV, AarABL B, Scalea TM. Association of CSF biomarkers and secondary insults following severe traumatic brain injury. Neurocrit Care. 2011;14:200-7.

27. Darwish RS, Amiridze NS. Detectable levels of cytochrome $C$ and activated caspase-9 in cerebrospinal fluid after human traumatic brain injury. Neurocrit Care. 2010;12:337-41.

28. Mondello S, Robicsek SA, Gabrielli A, Brophy GM, Papa L, Tepas J, Robertson C, Buki A, Scharf D, Jixiang M, Akinyi L, Muller U, Wang KK, Hayes RL. all-spectrin breakdown products (SBDPs): diagnosis and outcome in severe traumatic brain injury patients. J Neurotrauma. 2010;27:1203-13.

29. Papa L, Akinyi L, Liu MC, Pineda JA, Tepas JJ 3rd, Oli MW, Zheng W, Robinson G, Robicsek SA, Gabrielli A, Heaton SC, Hannay HJ, Demery JA, Brophy GM, Layon J, Robertson CS, Hayes RL, Wang KK. Ubiquitin C-terminal hydrolase is a novel biomarker in humans for severe traumatic brain injury. Crit Care Med. 2010;38:138-44.

30. Brouns R, De Vil B, Cras P, De Surgeloose D, Mariën P, De Deyn PP. Neurobiochemical markers of brain damage in cerebrospinal fluid of acute ischemic stroke patients. Clin Chem. 2010;56:451-8.

31. Fountas KN, Tasiou A, Kapsalaki EZ, Paterakis KN, Grigorian AA, Lee GP, Robinson JS Jr. Serum and cerebrospinal fluid C-reactive protein levels as predictors of vasospasm in aneurysmal subarachnoid hemorrhage. Clinical article Neurosurg Focus. 2009;26:E22.

32. Pineda JA, Lewis SB, Valadka AB, Papa L, Hannay HJ, Heaton SC, Demery JA, Liu MC, Aikman JM, Akle V, Brophy GM, Tepas JJ, Wang KK, Robertson CS, Hayes RL. Clinical significance of alphall-spectrin breakdown products in cerebrospinal fluid after severe traumatic brain injury. J Neurotrauma. 2007;24:354-66.

33. Lewis SB, Velat GJ, Miralia L, Papa L, Aikman JM, Wolper RA, Firment CS, Liu MC, Pineda JA, Wang KK, Hayes RL. Alpha-II spectrin breakdown products in aneurysmal subarachnoid hemorrhage: a novel biomarker of proteolytic injury. J Neurosurg. 2007;107:792-6.

34. Ost M, Nylén K, Csajbok L, Ohrfelt AO, Tullberg M, Wikkelsö C, Nellgård P, Rosengren L, Blennow K, Nellgård B. Initial CSF total tau correlates with 1-year outcome in patients with traumatic brain injury. Neurology. 2006;67:1600-4.

35. Selakovic V, Raicevic R, Radenovic L. The increase of neuron-specific enolase in cerebrospinal fluid and plasma as a marker of neuronal damage in patients with acute brain infarction. J Clin Neurosci. 2005;12(5):542-7.

36. Zemlan FP, Jauch EC, Mulchahey JJ, Gabbita SP, Rosenberg WS, Speciale SG, Zuccarello M. C-tau biomarker of neuronal damage in severe brain injured patients: association with elevated intracranial pressure and clinical outcome. Brain Res. 2002;947:131-9.

37. Aurell A, Rosengren LE, Karlsson B, Olsson JE, Zbornikova V, Haglid KG. Determination of S-100 and glial fibrillary acidic protein concentrations in cerebrospinal fluid after brain infarction. Stroke. 1991;22:1254-8.

38. Strand T, Alling C, Karlsson B, Karlsson I, Winblad B. Brain and plasma proteins in spinal fluid as markers for brain damage and severity of stroke. Stroke. 1984;15:138-44.

39. Jha RM, Puccio AM, Chou SH, Chang CH, Wallisch JS, Molyneaux BJ, Zusman BE, Shutter LA, Poloyac SM, Janesko-Feldman KL, Okonkwo DO, Kochanek PM. Sulfonylurea receptor-1: a novel biomarker for cerebral edema in severe traumatic brain injury. Crit Care Med. 2017;45:e255-64.

40. Martínez-Morillo E, Childs C, García BP, Álvarez Menéndez FV, Romaschin AD, Cervellin G, Lippi G, Diamandis EP. Neurofilament medium polypeptide (NFM) protein concentration is increased in CSF and serum samples from patients with brain injury. Clin Chem Lab Med. 2015;53:1575-84.

41. Bellander BM, Olafsson IH, Ghatan PH, Bro Skejo HP, Hansson LO, Wanecek $M$, Svensson MA. Secondary insults following traumatic brain injury enhance complement activation in the human brain and release of the tissue damage marker S-100ß. Acta Neurochir (Wien). 2011;153:90-100.

42. Grossetete M, Phelps J, Arko L, Yonas H, Rosenberg GA. Elevation of matrix metalloproteinases 3 and 9 in cerebrospinal fluid and blood in patients with severe traumatic brain injury. Neurosurgery. 2009;65:702-8.

43. Cardali S, Maugeri R. Detection of alphall-spectrin and breakdown products in humans after severe traumatic brain injury. J Neurosurg Sci. 2006:50:25-31.

44. Farkas O, Polgár B, Szekeres-Barthó J, Dóczi T, Povlishock JT, Büki A. Spectrin breakdown products in the cerebrospinal fluid in severe head injury-preliminary observations. Acta Neurochir (Wien). 2005;147:855-61. 
45. Kay AD, Petzold A, Kerr M, Keir G, Thompson EJ, Nicoll JA. Cerebrospinal fluid apolipoprotein E concentration decreases after traumatic brain injury. J Neurotrauma. 2003;20:243-50.

46. Franz G, Beer R, Kampfl A, Engelhardt K, Schmutzhard E, Ulmer H, Deisenhammer F. Amyloid beta 1-42 and tau in cerebrospinal fluid after severe traumatic brain injury. Neurology. 2003;60:1457-61.

47. Raby CA, Morganti-Kossmann MC, Kossmann T, Stahel PF, Watson MD, Evans LM, Mehta PD, Spiegel K, Kuo YM, Roher AE, Emmerling MR. Traumatic brain injury increases beta-amyloid peptide 1-42 in cerebrospinal fluid. J Neurochem. 1998;71:2505-9.

48. Nathoo N, Chetty R, van Dellen JR, Barnett GH. Genetic vulnerability following traumatic brain injury: the role of apolipoprotein E. Mol Pathol. 2003;56:132-6.

49. Chesnut RM, Marshall LF, Klauber MR, Blunt BA, Baldwin N, Eisenberg HM, Jane JA, Marmarou A, Foulkes MA. The role of secondary brain injury in determining outcome from severe head injury. J Trauma. 1993;34:216-22.
50. Sonnemann KJ, Bement WM. Wound repair: Toward understanding and integration of single-cell and multicellular wound responses. Annu Rev Cell Dev Biol. 2011;27:237-63.

51. Hadass O, Tomlinson BN Gooyit M, Chen S, Purdy JJ, Walker JM, Zhang C, Giritharan AB, Purnell W, Robinson CR 2nd, Shin D, Schroeder VA, Suckow MA, Simonyi A, Sun GY, Mobashery S, Cui J, Chang M, Gu Z. Selective inhibition of matrix metalloproteinase- 9 attenuates secondary damage resulting from severe traumatic brain injury. PLoS One. 2013;8:e76904.

52. Gerber J, Tumani H, Kolenda H, Nau R. Lumbar and ventricular CSF protein, leukocytes, and lactate in suspected bacterial CNS infections. Neurology. 1998;51:1710-4.

\section{Publisher's Note}

Springer Nature remains neutral with regard to jurisdictional claims in published maps and institutional affiliations.
Ready to submit your research? Choose BMC and benefit from:

- fast, convenient online submission

- thorough peer review by experienced researchers in your field

- rapid publication on acceptance

- support for research data, including large and complex data types

- gold Open Access which fosters wider collaboration and increased citations

- maximum visibility for your research: over $100 \mathrm{M}$ website views per year

At BMC, research is always in progress.

Learn more biomedcentral.com/submissions 